\title{
Mosul Journal of Nursing
}

www.mjn.mosuljournals.com

\section{Oxidative Stress in Patients with Rheumatoid Arthritis}

Article information

Article history:

Received January 21, 2018

Accepted February 26, 2018

Available online March 17, 2018

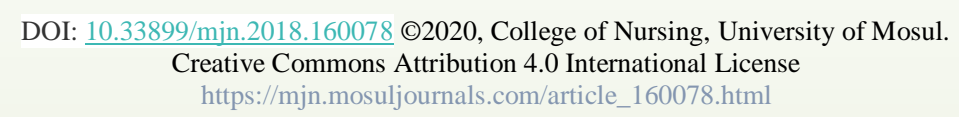

Amina Hisham Mohammed ${ }^{1}$

Kassim Salih Abdullah Al Neaimy ${ }^{2}$

\begin{abstract}
Background: There is a relationship between oxidative stress and rheumatoid arthritis.

Objective: To assess oxidative stress parameters represented by total antioxidant status and malondialdehyde, in patients with rheumatoid arthritis.

Design: case -control study.

Setting: Referred patients from private clinics .

Methodology: The study was conducted on patients with rheumatoid arthritis, referred from private clinics of rheumatology. The study period from Nov. ${ }^{\text {st }} 2017$ and Jun. $1^{\text {st }}$ 2018. Thirty-four female with rheumatoid arthritis, and thirty, sex and age-matched healthy volunteers as control group were participated in the study. Total antioxidants status and malondialdehyde were measured in both groups.

Results: Rheumatoid Arthritis patients have lower total antioxidants status values than that of the control group $(0.94 \pm 0.24$ and $1.95 \pm 0.20$ respectively) ( $\mathrm{P}$ value $<0.0001)$. The malondialdehyde values was higher in patients group than control group $(1.34 \pm 0.42$ and $0.88 \pm 0.26$ respectively) ( $\mathrm{P}$ value $<0.0001)$.

Conclusion: Rheumatoid Arthritis patients have decreased level of total antioxidants status and increased level of malondialdehyde than the control group .

Key words: Antioxidant status, Oxidative stress, Rheumatoid Arthritis
\end{abstract}

${ }^{1}$ MSc, University of Mosul, College of Medicine, Department of Pharmacy,

${ }^{2} \mathrm{PhD}$ ، Mosul University, College of Medicine Department of Pharmacology ، E-mail:abdullahkassim@yahoo.com Mobile: 009647701676407 


\section{Mosul Journal of Nursing, Vol. 6, No. 1, 2018 ( 17-22 )}

\section{Introduction}

Rheumatoid arthritis (RA) is multisystem chronic autoimmune disease of unknown aetiology with prevalence up to $1-2 \%$ of the total world population (Mclnnes and Georg, 2017, p2328), causing destruction of joint, ligaments, and tendons, which lead to physical disability (Kumar et $a l .$, 2016, p 510). Women are affected more than men (Phaniendra et al., 2015, p11).

Although the onset is more frequent in 40 's or 50's, RA can affect individuals of any age (Gibofsky, 2012, p295)

There is no single etiologic factor and it is a multifactorial, affect the susceptible host that trigger reactions leading to RA (Desai et al., 2010, p959).

Oxidative stress has been defined as the imbalance of oxidant/antioxidant forces in favor of the oxidant (Ibrahim et al., 2008, p195). In the lack of adequate antioxidant protections, oxygen radicals can cause oxidation of macromolecules resulting in oxidative damage of lipids, proteins and DNA (Griffiths et al., 2002, p875).

Researchers are interested to determine the cause of RA. It is thought that certain environmental factors such as infection could stimulate the immune system in susceptible individuals to cause inflammation in multiple tissues (Chandankhede and Gupta, 2013, p3088). In the same time during the inflammatory processes, and during the activation of neutrophil granulocytes, macrophages and lymphocytes, the oxygen and nitrogen species produced . The generation of free radicals (FR), especially oxygen species and nitrogen species (OS/NS) induce cartilage damage through either degradation of matrix or activation of matrixmetalloproteinases (MMPs) (Zheng et al., 2017, p1923).
Although RA is an autoimmune inflammatory disease whose pathogenic mechanisms remain to be elucidated, it is clear that oxidative stress contribute in the disease process; therefore, this study was aimed to:

1. Evaluate the antioxidant status of RA patients.

2. Evaluate the oxidative stress in patients with RA.

\section{Subjects and methods}

The study had approval from Mosul College of Medicine. Thirty-four female patients whose ages range between (35-50) years, known to have Rheumatoid Arthritis (RA) according to the American College of Rheumatology (ACR), receiving conventional treatment, enrolled in this study. Another thirty healthy subjects , were considered as a control group.

Individuals receiving trace element, antioxidants or vitamin B complex, smokers and alcohol users, patients with acute or chronic illness other than RA, were excluded from study.

Total antioxidants status was measured using Randox TAS kit (London - UK) (Miller et al., 1993, p704)

Serum MDA level, measured using thiobarbiturc acid (TBA) assay. (Buege, and Aust, 1978, p302) .

\section{Statistical analysis}

Unpaired T-Test was used to identify the variation in these variables. All values expressed as Mean \pm SD and $P$ value of $<0.05$ was considered to be statistically significant (Kirkwood , 1988, p43).

\section{Results:}

The individuals in the RA and control groups were comparable in terms of age, as shown by non statistically significant differences between the groups $(\mathrm{p}>0.5)$ as shown in table (1). Table (2) Shows the results of comparisons of TAS and MDA between studied groups. 
Mosul Journal of Nursing, Vol. 6, No. 1, 2018 ( 17-22 )

Table (1): The age of the studied groups.

\begin{tabular}{c|ccc}
\hline Parameters & $\begin{array}{c}\text { Patients } \\
(\mathbf{n = 3 4})\end{array}$ & $\begin{array}{c}\text { Control } \\
(\mathbf{n}=\mathbf{3 0})\end{array}$ & P value \\
\hline Age (years) & $42.79 \pm 10.30$ & $40.10 \pm 8.17$ & 0.256
\end{tabular}

There are very significant differences between patients group and control (p-value $=0.000$ ), regarding TAS and MDA value as shown in table (2)

Table (2): TAS and MDA serum level of the studied groups.

\begin{tabular}{c|ccc}
\hline Parameters & $\begin{array}{c}\text { Patients } \\
(\mathbf{n}=\mathbf{3 4})\end{array}$ & $\begin{array}{c}\text { Control } \\
(\mathbf{n}=\mathbf{3 0})\end{array}$ & P value \\
\hline TAS $(\mathbf{m m o l} / \mathbf{L})$ & $0.94 \pm 0.24$ & $1.95 \pm 0.20$ & 0.000 \\
& & & \\
& & & \\
$\mathbf{M D A}(\boldsymbol{\mu m o l} / \mathbf{L})$ & $1.34 \pm 0.42$ & $0.88 \pm 0.26$ & 0.000
\end{tabular}

\section{Discussion}

The present study was performed to assess the antioxidant status in a sample of RA patients by measuring total antioxidant status (TAS), in a parallel way; oxidative status was evaluated, by measurement plasma levels of a byproduct of lipid peroxidation, i.e. malondialdehyde (MDA).

The current study involved 64 individuals divided into 2 groups of 34 , and 30 for RA patients and control subjects respectively. Both groups were matched concerning their ages as confirmed statistically by the absence of significant differences between the studied groups. This matching of individual groups may exclude any effect of this factor on the results of the study. The removal of this factor interference with results of clinical trials were done in the majority of other trials concerning antioxidant field (Jimenez-Jimenez et al., 1998, p75; Besler et al., 2003, p78; Besler and Comoglu 2003, p189; Miller et al., 2011,p1012) .

The present study demonstrated that TAS level was lower in RA patients $(0.94 \pm 0.24 \mathrm{mmol} / \mathrm{l})$, when compared with the control group $(1.95 \pm 0.20$ $\mathrm{mmol} / \mathrm{l}),(\mathrm{P}=0.001)$. These results are in accordance with studies done by (Shah et al., 2011, p1010; Mohammed et al.,2016, p2591)

Jaswal et al., (2003) assessed total oxidant status (TOS), and total antioxidant status (TAS) in 40 RA patients; they found RA patients have low level of antioxidants and high plasma level of MDA.

Zhou et al., (2017) found in their study that patients with RA have low level of TAS compared to control.

Gansu, (2018) compared TAS, oxidants index level between 35 RA women patients, and 35 control, and found patients have low level of TAS and higher level of oxidants stress index than control. 


\section{Mosul Journal of Nursing, Vol. 6, No. 1, 2018 ( 17-22 )}

In this study, oxidative stress was assessed in terms of MDA, and it was found that serum MDA levels were higher in patients with RA $(1.34 \pm 0.42$ $\mu \mathrm{mol} / \mathrm{l})$ than the healthy control subjects $(0.88 \pm 0.26 \mu \mathrm{mol} / \mathrm{l}) \mathrm{p}<0.001$. Our findings are in agreement with the results obtained by Shaabani et al.,(2009) ( Similar results of increased MDA levels have been reported in patients with rheumatoid arthritis (Gambhiri et al., 1997, p351; Karatas et al., 2003, p178; Walwadkar et al., 2006, p134; Ansari et al., 2008, p429; El-barbary et al., 2011, p179; Marie et al., 2017, p47).

Increased MDA level is an evidence of exaggerated oxidative stress in these patients.

Recent evidence suggests that articular chondrocytes can actively produce OS, which are produced during inflammation of the synovial membrane. These OS with oxidative activity participate in the chondrocyte catabolism, being the mediators and effecters of cartilage damage (Vyas et al., 2016, p58)

Our question arises whether oxidative stress in RA, play a role in pathology or it is a non-specific process. Evidence for an important contribution of oxidative stress in the development RA, should be based on clinical trials that combine antioxidant drugs with conventional antirheumatic drugs. However, clinical trials of antioxidant treatments in RA are lacking.

Conclusion: TAS levels were lower in RA patients, and higher level of MDA than the control group . Therapy with antioxidants vitamins such as $E$ and $\mathrm{C}$ can be used as adjunct to other therapies of RA.

\section{References}

Ansari S and Jaiswal G. (2008). Oxidative status in rheumatoid arthritis-a biomedical study. Antiseptic j 105:p429-431.

Besler ,Sackesen C, Ercan H, Dizdar E, Soyer O, Gummus P, et al,.( 2008) A comprehensive evaluation of the enzymatic and non-enzymatic antioxidant systems in childhood asthma. J aller clin immu.122(1).p7885 .

Besler HT, and Comoglu S. (2003) Lipid peroxidation, plasma total antioxidant capacity and homocystiene level in patients with multiple seclerosis. Nutr neurosci j.6(3).p18996.

Buege JA, Aust SD. (1978). Microsomal lipid peroxidation. In: Method in enzymology. Bio membranes. Part C: Biological oxidation Microsomal, Cytochrome P450 and other hem protein system. Flescher S, Packer $L$ editor. San Francisco London. 52.p302- 306.

Chandankhede MS, Gupta MM. 2013). Oxidative stress and antioxidant status in patients with rheumatoid arthritis; Int J Biol Med Res.4(2).p3088-3090.

Desai Prakash B, Manjunath S, KadiSumangala K, Chetana, Vanishree J. (2010). Oxidative stress and enzymatic antioxidant status in RA: a case control study. Euro Revi Medi Pharmac sci.14.p959-967.

El-barbary AM, Khalek MAA, Elsalawy AM, Hazaa SM. (2011). Assessment Lipid peroxidants \& antioxidants status in Rheumatoid Arthritis and Osteoarthritis Patients. The Egy Rheuma j. 33(4).p179-185.

Gambhiri JK, Lali P, Jan AK. (1997). Correlation between blood antioxidants level and lipid peroxidation in rheumatoid arthritis. Clin Biochem.30(4).p351- 355. 


\section{Mosul Journal of Nursing, Vol. 6, No. 1, 2018 ( 17-22 )}

Gansu B. (2018). Romatoid Artriti Yetiskin Kadinlarin AKdeniz Diyetine Uymu ile Serum Toplam AntioKsidan Durumlari Arasindaki Iliskinin Belirlenmesi. Saglik Bilimleri Enstitusu.

http://hdl.handle.net/11655/4618.

Gibofsky A. (2012). Overview of epidemiology, pathophysiology, and diagnosis of rheumatoid arthritis. Amer $J$ Manage and Care.18(13).pS295S302.

Griffiths HR, Lunec J, Holloway KA, Cooke MS, Faux S, Evans MD. (2002). Urinary 8-oxo-2deoxyguansine: redox regulation of DNA repair in vivo. Free radi Biol Medi.33(7).p875-885.

Ibrahim MA, Ibrahim MH, Ayoub HA. (2008). Diabetes mellitus as an oxidative stress. Rom $J$ Biophys. 18.p195-208.

Jaswal S, Mehta HC, Sood AK, Kaur J. (2003). Antioxidants status in Rheumatoid Arthritis and Role of antioxidant therapy. Clin Chem Acta.388(1-2).p123-129.

Jimenez- Jiménez FJ, Bustos F, Molina JA, Andres C, Gassalla T, Orti-Pareja M, et al,. (1998). Cerebrospinal fluid levels of alpha-tocopherol in patients with multiple seclerosis. Neuroscience Letters.249(1).p65-67.

Karatas F, Ozates I, Canatan H, Halifeoglu I, Karatepe M, Colakt R. (2003). Antioxidant status \& lipid peroxidation in patients with rheumatoid arthritis. Indi J Medi Res; 118:178- 181 .

Kirkwood BR. (1988). Essential of Medical statistics (1st ed). Blackwell Scientific publications, Oxford: 43-56.

Kumar V, Bhatt PC, Rahman. (2016). Melastoma malabathricum Linn attenuates complete freund's adjuvantinduced chronic inflammation in wistar rats via inflammation response. $B M C$ Complement Altern Med.p510-516.

Marie DB, Ateba G, Felicite KD, Fernando KL, Mark Chia A, Henry LN. (2017). Oxidative Stress in Patients with Chronic Inflammatory Diseases in a Tertiary Health Care Setting in Africa. $J$ Autoimm Disor.3(4).p47.

Mclnnes LB, and Georg-Schet MD. (2017) Pathogenetic insights from the treatment of rheumatoid arthritis. The Lancet.389(10089).p2328-2337.

Miller E, Mrowicka M, Saluk-Juszczak J, Ireneusz M. (2011). The level of isoprostanes as a non-invasive marker for in vivo lipid peroxidation in secondary progressive multiple sclerosis. Neurochem Res.36.p10121016.

Miller NJ, Rice -Evans C, Davies MJ, Gopinathan V, Milner A (1993). A novel method for measuring antioxidant capacity and its application to monitoring the antioxidant stats in premature neonates. Clin sci. 84(4).p407-412.

Mohammed MB, Khelil S, Dbibis MB, Khlifi L, Chahed H, Ferchichi E, et al. (2016). A case control study of antioxidant and oxidant status in Tunisian rheumatoid arthritis patients. Inter J pharmac Scie Res.7(6).p25912596.

Phaniendra A, Jestadi DB, and Periyasamy L. (2015). Free radicals: properties, sources, targets, and their implication in various diseases. Indi $J$ Clin Bioche.30(1).p11-26.

Shaabani Y, Foroughi M, Rastmanesh R, Jamshidi A, Tajik N, Assadi O.( 2009). Assessment of antioxidant nutrient Intake and malondiadehyde plasma level in Rheumatoid arthritis. Atheros j.5(1).pl-5. 
Shah D, Wanchu A, Bhatnagar A. (2011). Interaction between oxidative stress and chemokines: possible pathogenic role in systemic lupus erythromatous and rheumatoid arthritis. Immunobio. 216(9).p10101017.

Vyas S, Sharma H, Vyas RK. (2016). Role of malondialhehyde in the serum of rheumatoid arthritis and osteoarthritis. $J$ Postgraduate Medi Institute.30(1).p58-61.

Walwadkar SD, Suryakar AN, Katkam RV, Kumbar KM, Ankush RD. (2006). Oxidative stress and calcium phosphorous levels in rheumatoid arthritis. Indi $J \quad$ Clin Biochem.21(2).p134-137.

Zheng K, Zhao Z, Lin N, Wu Y, Xu Y, Zhang W. (2017). Protective Effect of Pinitol Against Inflammatory Mediators of Rheumatoid Arthritis via Inhibition of Protein Tyrosine Phosphatase Non-Receptor Type 22 (PTPN22). Med Sci Monit.p19231932.

Zhou L, Feng JT, Zhang L, Kuang Y. (2017). Clinical significance of serum total oxidant/antioxidant status for the disease activity in active rheumatoid arthritis. Inter $J$ Clin Patho. 10(8).p8895-8900. 